\title{
Note on the Rules of International Court Jurisdiction in Civil Matters with respect to the Bill of the New Organic Law governing the Spanish Judiciary
}

\author{
María Teresa Alcolado Chico*
}

SYNTHESIS: I.- The legislative panorama prior to Organic Law 6/1985 governing the Spanish Judiciary, passed in Spain on Ist July 1985. 2.- From the LOPJ to the Bill of the new Law. 3.- General overview of the regulation of international court jurisdiction in civil matters in the Bill of the new LOPJ. 4.- Conclusion.

\section{THE LEGISLATIVE PANORAMA PRIOR TO ORGANIC LAW 6/1985 GOVERNING THE SPANISH JUDICIARY, PASSED IN SPAIN ON IST JULY 1985}

Organic Law 6/1985 governing the Spanish Judiciary, passed in Spain on Ist July 1985, ${ }^{1}$ definitively resolved the doubts about jurisprudence and case law itself that earlier legislation had raised in respect of the international jurisdiction of Spanish courts in civil matters. This earlier legislation started with the Decree of 6th December I868², which was passed by the Provisional Government of general Serrano and signed by the minister of clemency and justice, Antonio Romero Ortiz. Section I of Title I, under the heading referenced "The consolidation of the special forums of ordinary courts", lays down: "As from the publication of this decree, only the ordinary courts shall have jurisdiction to hear [...]" and section 6 on "Civil matters and criminal prosecutions of foreign nationals domiciled or transient", which is why it was known as decree on unification of forums. It only centred on determining that said ordinary courts would have jurisdiction over civil matters, and not other special courts that hitherto had jurisdiction over specific areas, such as the forum for foreign nationals, ${ }^{3}$ when there was a foreign element in a civil case. The latter jurisdiction was abolished together with other

\footnotetext{
Professor of private international law at the university college of "Cardenal Cisneros" and at the university college of Financial Studies (CUNEF), officially attached to the Universidad Complutense de Madrid. Member of the Spanish Royal Academy of Jurisprudence and Legislation (Corresponding Member). Barrister and member of the Madrid Bar Association.

Hereinafter, LOPJ (Ley Orgánica 6/1985 del Poder Judicial, passed in Spain on I ${ }^{\text {st }}$ July 1985).

Published in Gaceta de Madrid on Monday, 7th December 1868, pp 2-6. Some authors mistakenly attribute a regulatory status to this decree that it does not have, thus Leonardo Prieto-Castro alludes to "R. D. of 6-XII-I868" which, without doubt, refers to "Royal Decree", v Exposición del Derecho procesal civil de España [Presentation of Spanish civil procedural law], vol. I, Zaragoza, 194I, p 6I. León Medina-Manuel Marañón refers to “Decree-Ley”, v Leyes Penales de España [Criminal laws of Spain], Io ${ }^{\text {th }}$ ed., Appendix, Madrid, 1947, p 32. By contrast, Universidad de Madrid gives the correct status. Chair of Private International Law: Textos y Materiales de Derecho Internacional Privado [Texts and material on private international law], vol. I, Textos y Documentos [Texts and documents], Madrid, 1970, p 75.

${ }^{3}$ On this theme v Pecourt García, E.: "Una institución singular en la bistoria del Derecho internacional privado español: el Fuero de Extranjería" ["A singular institution in the history of Spanish private international law: the Forum for Foreign Nationals], in Estudios de Derecho Internacional Público y Privado [Studies of public and private international law]. Homenaje al profesor Luis Sela Sampil [Tribute to professor Luis Sela Sampil], vol. III, Oviedo, I970; Blanco Ande, J.: El Fuero de Extranjería en España [Forum for foreign nationals in Spain], doctoral thesis unpublished, Madrid, I975; also, Puente Egido, J.: Derecho internacional privado español : doctrina legal del Tribunal Supremo [Spanish private international law: case law handed down by the Supreme Court] (184I-1977), Barcelona, 1981, pp 3-I8; Tomás Ortiz de la Torre, J. A.: "Una obra inédita sobre Derecho internacional privado del profesor Mariano Aguilar Navarro (1916-1992)" ["Unprecedented work on private international law by professor Mariano Aguilar Navarro (1916-1992)"], in Revista Jurídica de Asturias [Law journal of Asturias], no. 34, 2010, pp 220-233;
} 
jurisdictions, such as that of the special Tax Courts and the Commercial Courts. Two years later, in consonance with said decree, section 267 of the Ley Provisional sobre Organización del Poder Judicial (provisional law on organisation of the Spanish judiciary), passed on I5th September 1870, laid down that: "Ordinary courts shall bave jurisdiction" to hear civil cases that arise in Spanish territory, between Spaniards, between foreign nationals and between Spaniards and foreign nationals". Subsequently, rule $5 \mathrm{I}$ of the Ley de Enjuiciamiento Civil (Spanish rules of civil procedure), 5 passed by Royal Decree of 3 rd February I88I, in force as from the following ${ }^{\text {st }}$ April, ${ }^{6}$ reproduced this text while adding that said ordinary courts were the only courts to have said jurisdiction. Moreover, section 27I of said provisional law of 1870 laid down that: "The foregoing provisions on jurisdiction shall cover foreign nationals that seek the jurisdiction of Spanish courts, filing pleas voluntarily and acting therein, or appearing in court, in their capacities as plaintiffs or defendants, against Spaniards or other foreign nationals in the event that Spain has jurisdiction to hear the case in accordance with the laws of the Kingdom of Spain or the Treaties signed with other powers". This reference, generic, had only been specified in sections 29, 32 and 33 of the Royal Decree governing foreign nationals of $17^{\text {th }}$ November I852, which laid down the circumstances under which foreign nationals were subject to the courts of Spain.

Some sectors of Spanish legal opinion said that judging from the broad spectrum of these precepts, it could be deduced that on abolishing the forum for foreign nationals through said decree of I868, law makers had vested the jurisdiction over all the cases that fell within said forum in the ordinary courts, which would explain the generality with which the Spanish R. Civil P (LEC) vested Spanish courts with jurisdiction over all litigation between foreign nationals or between Spaniards and foreign nationals. And since rule 70 of the LEC reproduces section 271 of the provisional law passed in 1870 , territorial jurisdiction was, in accordance with section 69 of said LEC, determined by the connecting factor of the defendant's domicile in Spain, in the absence of which, his residence, or otherwise by the place in which he was living at the time or by his most recent residence, at the discretion of the plaintiff. Some authors pointed out, however, and rightly so, that even with this broad spectrum of subsidiary domicile connecting factors, the possibility of summoning a foreign national to appear before the courts of Spain required "a certain contact between said foreign national with Spanish territory", and that "with such inaccurate elements of legal judgment, it is not surprising that legal opinion did not arrive at unanimous conclusions about the international territorial jurisdiction of Spanish courts" 7 .

The italics are mine.

Hereinafter, LEC (Ley de Enjuiciamiento Civil).

These R. Civil P. (LEC) were preceded by the Ley de Enjuiciamiento del Comercio (Rules of commercial procedure) of 1830 and the Reglamento para la Administración de Justicia (regulations governing the administration of justice) of 1835 and the law of Ioth January 1838 which endeavoured to fill the lacunae of said regulations. On 30 th September 1853 , a few days after the arrival to the Ministry of Clemency and Justice of Judge José de Castro y Orozco, the Instruction on civil procedure in respect of ordinary royal jurisdiction was published, but opposition, particularly from the Madrid Bar Association, led to its abolishment in May I854. Thus in May 1855 the fundamental provisions of a law were drafted to create one single law on civil procedure which came to fruition on the following $5^{\text {th }}$ October, in which task Pedro Gómez de la Serna played an important role. The LEC of 1855 was severely criticised and, with a few finishing touches, was in force in Spain for a little over a quarter of a century but, nonetheless, it served as a model to draft the fundamental provisions of a new law from which the LEC of I88I was created.

7 See, for instance, Miaja de la Muela, A.: Derecho internacional privado, II, Parte especial [Private international law, II, Special part], 7th ed., Madrid, 1977, p 45r. The position of Spanish legal opinion at the time and case law may be seen under the heading of "Legislación española" [Spanish legislation] on pp 449-459. 
More than one century after passing the LEC, these doubts were resolved with the coming into force of the LOPJ of 1985 , which dedicates its section 22 to specifying the substantial relationships - the connecting factors - that determine the international jurisdiction of Spanish courts in civil matters.

\section{FROM THE LOPJ TO THE BILL OF THE NEW LAW}

The LOPJ of 1985 specifies in section 2I.I that: "Spanish courts shall hear the cases that arise in Spanish territory between Spaniards, between foreign nationals and between Spaniards and foreign nationals in accordance with the provisions of this law and with the international treaties and conventions to which Spain is a signatory", and in section 2I.2 that: "The circumstances of immunity from jurisdiction and enforcement provided for by the rules of International Public Law are excepted". Section 22 goes on to set forth the criteria and relationships or connecting factors that establish the international jurisdiction that Spanish courts have in civil matters, which jurisdiction, depending on its nature, is governed by specific sub-sections, namely "exclusive in nature" (subsection I), "general in nature" (sub-section 2), 9 circumstances "in the absence of the foregoing criteria" (sub-section 3), "in regard to consumer contracts" (sub-section 4 ) $^{\mathrm{II}}$ and in regard to adoption of "provisional measures" in respect of persons or property (sub-section 5$)^{\mathrm{I2}}$.

8 Section 22: "In civil cases, the Spanish courts shall have jurisdiction: I Of an exclusive nature, in regard to in rem rights and tenancies of immovable properties that are in Spain; in regard to incorporation, validity, nullity or dissolution of companies or legal entities that are domiciled in Spanish territory as well as in respect of the resolutions and decisions adopted by their managing bodies; in regard to validity or nullity of entries made in a Spanish Register; in regard to registrations or validity of patents and other rights submitted to deposit or register when said deposit or register is requested or effected in Spain, and in regard to recognition and enforcement in Spanish territory of court judgments and arbitration awards delivered abroad.".

9 "2. General in nature, in the event that the parties have expressly or tacitly submitted to the Spanish courts and where the defendant is domiciled in Spain".

10 "3. In the absence of the foregoing criteria and in regard to presumption of absence or death, if the missing person's most recent domicile was in Spanish territory; in regard to incapacity and protective measures of the physical integrity and assets of minors and incapacitated persons, if the latter habitually reside in Spain; in regard to personal and estate relations between spouses, nullity of marriage, separation and divorce, if both spouses habitually reside in Spain at the time of the petition or if the petitioner is Spanish and habitually resides in Spain as well as in the event that both spouses have Spanish nationality, regardless of their place of residence provided that they file their petition by mutual agreement or one does so with the consent of the other; in regard to filiation and parent-children relations, in the event that the child resides habitually in Spain at the time of the petition or that the petitioner is Spanish or habitually resides in Spain; for the formalization of adoption, if the adopter or the adopted is Spanish or habitually resides in Spain; in regard to maintenance, where the recipient of same habitually resides in Spanish territory; in regard to contractual obligations where they have arisen or must be observed in Spain; in regard to extra-contractual obligations, where the event from which they derive has occurred in Spanish territory or the author of the damage and the victim habitually reside in Spain; in proceedings relating to moveable assets, if they are in Spanish territory at the time of the action, and, in regard to succession, where the decedent has had his most recent domicile in Spanish territory or possesses immovable property in Spain".

II "4. Likewise, in regard to consumer contracts, where the buyer is domiciled in Spain, if the transaction involves a sale by installment of corporeal movable objects or loans granted to finance the acquisition of said objects, and in the event of any other contract in relation to the provision of services or movable assets where prior to signing the contract, a personal offer has been made or advertising run in Spain or the consumer has conducted the acts required to enter into the contract in Spanish territory; in regard to insurance, where the insured and the insurer are domiciled in Spain, and in litigation relating to the operation of a branch, bureau or commercial establishment, where this is located in Spanish territory. In regard to bankruptcy, this shall be governed by the law applicable thereto".

I2 "5. In cases where provisional, precautionary or preventive measures are adopted in respect of persons or property located in Spanish territory, which must be observed in Spain”. 
Several aspects can be highlighted from the precept as a whole, such as the inspiration drawn from the Brussels Convention of $27^{\text {th }}$ September 1968 governing court jurisdiction and the enforcement of court judgments in civil and commercial matters. Said Convention would later have a bearing on section 22.I of the LOPJ once the former came into force in Spain, which obviously occurred when Spain became a member of the European Communities, today the European Union. In section 22.3, there is a lack of logic-time order in relation to the matters concerning "personal statute" and also, in matters of voluntary jurisdiction, the margin established to determine international jurisdiction in regard to absence and presumption of death is very limited since, according to the rule, the courts do not have jurisdiction in the extraordinary case in which all the persons concerned, including the deceased presumptive, are Spanish residents in Spain. A case in point might be, for example, a plane accident of an aircraft flying under the Spanish flag occurring in Spanish territory. This lack of jurisdiction derives from the simple fact that the deceased presumptive is domiciled abroad, which limitation is inexplicable and incomprehensible. What would happen if in the State of the domicile of the deceased presumptive, "domicile" were not sufficient for its authorities to establish whether they have jurisdiction to hear such a case?

For said Brussels Convention of $27^{\text {th }}$ September 1968 to take effect in Spain, almost all of section 22.I of the LOPJ had to be amended accordingly, which was replaced by the text of article 16 of said Convention. I say "almost" all because of the original version of the LOPJ, the only part remaining in force was the reference to the "arbitration awards made abroad" given that the Convention of 1968 excluded "arbitration" from its scope of application (art. I.4). Even the reference to "court judgments" of the text of the LOPJ was replaced with the same reference ("court judgments" of article 16.5 of the Convention of 1968 because in the latter, the part relating to "court jurisdiction" was of universal application (naturally under the conditions that said Convention laid down), while the rules regulating "recognition and enforcement" were applicable in a reciprocal manner, i.e., limited to the court judgments handed down by the courts of the Member States of the European Union. Therefore, the authorisation to enforce the judgments from third States was subject to the rules regulating any multilateral or bilateral convention to which Spain might be a signatory or otherwise to the rules from an internal source which, today, continue to be rules 95I to 958 of the old LEC of I88I, as in force at the present time after the amendments to rule 955 thereof by virtue of Act II/20II of $20^{\text {th }}$ May 201 and Act $13 / 2009$ of $3^{\text {rd }}$ November 2009.

The replacement of the Brussels Convention with Council Regulation (EC) number 44/200I of 22nd December 2000, in force in Spain at the time this text is written, meant a new amendment to section 22.I of the LOPJ in order to adapt it to article 22 of said EC Regulation. Although the latter reproduces the text of the Brussels Convention, it introduces some innovations. In regard to tenancy of immovable property for private use, the Brussels Convention required both landlord and tenant to be natural persons while in the EC Regulation this is only required of the tenant, and in regard to registrations or validity of patents, the EC Regulation adds a paragraph. ${ }^{\mathrm{I} 3}$ Accordingly, at the present

\footnotetext{
13 There follows a text currently in force in Spain of article 22 of Regulation (EC) 44/200I: "The following courts shall have exclusive jurisdiction, regardless of domicile:

"I. In proceedings which have as their object rights in rem in immovable property or tenancies of immovable property, the courts of the Member State in which the property is situated.

"However, in proceedings which have as their object tenancies of immovable property concluded for temporary private use for a maximum period of six consecutive months, the courts of the Member State in which the defendant is domiciled shall also have jurisdiction, provided that the tenant is a natural person and that the landlord and the tenant are domiciled in the same Member State;

"2. In proceedings which have as their object the validity, the nullity or the dissolution of companies or other legal entities, or of the validity of the resolutions or decisions adopted by their governing bodies, the courts of the Member State
} 
time, the text of section 22.I of the LOPJ reproduces that of article 22 of EC Regulation 44/200I, though the addition of "arbitration awards" remains since said Regulation also excludes "arbitration" (article I.2 d).

Likewise, on Ioth January 2015, when Regulation (EU) number $1215 / 2012$ of the European Parliament and the Council of I2th December 20I2, ${ }^{14}$ substituting for Regulation 44/200I, takes effect in Spain, the rules on exclusive jurisdiction of the new EU Regulation, which continues to exclude arbitration from its scope, will once again affect section 22.I of the LOPJ. Whatever the definitive text of the new LOPJ might be, the precept on exclusive jurisdiction of Regulation (EU) 1215/2012 will replace, once it comes into force in Spain, the Spanish rule on exclusive jurisdiction, of which only said reference to "arbitration awards" will remain since the new EU Regulation excludes arbitration from its scope, as did its predecessors. Therefore, excepting this reference which is regulated by the Spanish law, the rest of the rule comes from said Regulation. This is exactly the same as what occurred when the Brussels Convention was in force and that occurs at the present time with Council Regulation 44/200I.

\section{GENERAL OVERVIEW OF HOW INTERNATIONAL COURT JURISDICTION IN CIVIL MATTERS IS}

\section{REGULATED IN THE BILL OF THE NEW LOPJ ${ }^{15}$}

Under the heading "International court jurisdiction", Title VII dedicates chapter I to "International court jurisdiction in civil matters", which is divided into ten sections: 59 (international court jurisdiction in civil matters); 60 (exclusive jurisdiction); 6I (submission to Spanish courts); 62 (general jurisdiction); 63 (special jurisdiction in regard to rights of the individual and family relations); 64 (special jurisdiction in regard to obligations and contracts); 65 (jurisdiction in regard to the adoption of provisional and precautionary measures); 67 (absence of international jurisdiction), and 68 (international lis pendens).

It should be pointed out that in section 59, the cognizance of Spanish courts extends to the cases that might arise in Spanish territory between Spaniards, between foreign nationals and between Spaniards and foreign nationals, in accordance with the provisions of Spanish laws and the treaties and conventions in force to which Spain is a signatory as well as "the regulations deriving from the

in which the company or legal entity has its registered office or headquarters. In order to determine said registered office or headquarters, the court shall apply its rules of private international law;

"3. In proceedings which have as their object the validity of entries in public registers, the courts of the Member State in which the register is kept;

"4. In proceedings concerning the registration or validity of patents, trademarks, designs, utility models, or other similar rights that are required to be deposited or registered, the courts of the Member State in which the deposit or registration has been applied for, has been completed or is deemed to have been completed under the terms of a Community instrument or an international convention.

"Without prejudice to the jurisdiction of the European Patent Office under the Convention on the Grant of European Patents, signed in Munich on $5^{\text {th }}$ October 1973, the courts of each Member State shall have exclusive jurisdiction, regardless of domicile, in proceedings that concern the registration or validity of any European patent granted for that State;

" 5 . In proceedings concerning the enforcement of judgments, the courts of the Member State in which the judgment has been or is to be enforced."

${ }^{14}$ Official Journal of the European Union of $20^{\text {th }}$ December 2012, L. 35I. This Regulation has already merited the attention of Spanish legal opinion and several articles published in blogs of international law barristers, such as P. de Miguel Asensio and F. Garau Sobrino, can be cited as well as articles and journal articles, such as that of the litigator J. A. Ortiz Pradillo, in Revista General de Derecho Procesal [Journal of procedural law], no. 29, January, 2013.

is The text of the Bill was approved by the Spanish cabinet on $4^{\text {th }}$ April 2014. 
institutions of the European Union", and "if the defendant summoned does not duly appear, in cases where the international jurisdiction of Spanish courts may only be grounded on the tacit submission of the parties".

Section 60, governing exclusive jurisdiction, follows the criteria of article 22 of Council Regulation (EC) 44/200I, but omits the paragraph in which the latter makes reference to "European patent", transcribed above, and in regard to recognition and enforcement of court judgments, it expressly cites "judgments", and naturally, as established in earlier versions, arbitration awards are respected and "agreements deriving from mediation conducted abroad are added".

With respect of express or tacit submission to Spanish courts, in accordance with section 6I, agreements attributing jurisdiction included in a contract shall not take effect if they are contrary to the provisions of sections 63 and 66 , or if jurisdiction is excluded when said jurisdiction is exclusive in accordance with section 60. Submission in regard to contracts of insurance entered into by consumers shall only be valid if the agreement is subscribed after the dispute has arisen, or if both contracting parties are domiciled in Spain when the contract is being subscribed or if the plaintiff is the consumer, the insured or the policy holder. In synthesis, the precept defines what has to be understood by express submission and how it has to be recorded in a document, on the understanding that tacit submission means the defendant will simply appear before the court as long as he does not do so to challenge the court's jurisdiction.

In accordance with section 62, in regard to matters other than those provided for in sections 60 , 65 and 66, in the absence of submission, the jurisdiction of Spanish courts is determined by the domicile in Spain of the defendant or when so determined by any of the forums laid down in sections 63 and 64. Said jurisdiction may, however, be excluded by a choice of court agreement (forum selection clause) in favour of a foreign court. In such case, the Spanish court shall suspend the proceeding and "may only hear the alleged claim filed in the event that the foreign court designated rejects its jurisdiction". A natural person's domicile is understood to be in Spain if said person habitually resides in Spain and in respect of a legal entity, if its registered office, head office or centre of main activity is in Spain. In cases where one plaintiff is claiming against multiple defendants, it will suffice that that at least one of the defendants is domiciled in Spain "provided that one single action is brought or several that are connected together by a link giving a ground (causa petendi) for requesting their joinder". The exclusion of the jurisdiction of Spanish courts in areas in which submission thereto is not permitted shall have no effect.

Within the area of rights of the individual and family relations, section 63, which takes the LOPJ currently in force as a model, provides that "in the absence of the foregoing criteria", Spanish courts have jurisdiction over six areas. The innovations in these areas introduced by the new text are as follows: presumption of absence or death where next to the criterion of the most recent domicile in Spain of the missing person, "or that he has Spanish nationality" is added, thereby extending the current criterion of jurisdiction but is, nevertheless, insufficient since causes such as natural catastrophe, air or sea accident that might have occurred in Spain should be borne in mind regardless of the nationality and the most recent domicile of the missing person; in regard to personal and estate relations, matrimonial nullity, and so forth, a reference to "amendments thereto" is introduced, and in regard to the criteria of jurisdiction, the content of article 3 of Council Regulation (EC) number $2201 / 2003$ of $27^{\text {th }}$ November 2003 concerning jurisdiction and the recognition and enforcement of decrees in matrimonial matters and the matters of parental responsibility is reproduced, which Regulation repeals Regulation (EC) number 1347/2000. This means that when in accordance with Regulation 2201/2003, there is no jurisdiction for Spanish courts, the solution will inexorably be the same on applying, in compliance with article 7 thereof, the laws of Spain for purposes of determining 
residual jurisdiction since Spanish law does not provide for circumstances other than those of the EC Regulation; in regard to filiation, "protection of minors and parental responsibility" is added as well as the criterion of jurisdiction "or, in any case, at least six months prior to the filing of the petition", in reference to the residence in Spain of the petitioner; in regard to adoption, "or, as the case may be, when the laws regulating international adoption so provide" is added, and lastly, in regard to maintenance, where the recipient of same or the respondent habitually resides in Spain or, if the petition for maintenance is filed as an accessory to a question on civil status or a petition in regard to parental responsibility, "when Spanish courts have jurisdiction to hear the latter".

Section 64 determines the "special jurisdiction in regard to obligations and contract law. In respect of extra-contractual obligations the only criterion established is "that the injurious event has occurred in Spain". The alternative in force at the present time is removed, namely "the author of the damage and the victim shall reside habitually in Spain", which is most unfortunate. In respect of contracts entered into by consumers, jurisdiction remains limited to whether the consumers are the complainants when they or the other contracting party habitually reside in Spain, but the consumer may only be brought to court by the other contracting party if the consumer habitually resides in Spain. In regard to insurance, the criteria are extended as follows: "if the insured, policy holder or beneficiary of the insurance policy is domiciled in Spain, an action may also be brought against the insurer before Spanish courts if the injurious event has occurred in Spanish territory and the policy in question is liability insurance or insurance covering immovable property, or in cases of third-party liability insurance, where Spanish courts have jurisdiction to hear the case brought by the injured party against the insured by virtue of the provisions of sub-section b) hereof', i.e., if the injurious event has occurred in Spanish territory. It should be pointed out that in regard to insurance policies subscribed by consumers, Spanish courts also have jurisdiction "if the consumer, insured or policy holder is the complainant and the parties have agreed to the submission to the Spanish courts when the dispute arises, or both contracting parties are domiciled in Spain at the time the contract is subscribed or that the complainant is the consumer, insured or policy holder". Lastly, in regard to successions which, incidentally, are surprisingly included under the heading of "obligations and contract law", the jurisdiction criteria are also extended in respect of the current criteria, such that there is jurisdiction "if the decedent had his most recent habitual residence in Spain or if the assets are located in Spain and the decedent was Spanish at the time of death", and there is also jurisdiction "if the parties have submitted to the Spanish courts provided that Spanish law is applicable to the succession", adding that "if no foreign court has jurisdiction, Spanish courts shall have, over the estate of the succession that is located in Spain".

Section 67 establishes that Spanish courts shall not have jurisdiction outside the forums of jurisdiction that are provided for. Whether or not there is jurisdiction shall be evaluated on the motion of the court or at the request of a party and the case shall be conducted until it is concluded even though the rules of jurisdiction or circumstances might subsequently change, while Spanish courts should establish their lack of cognizance where the jurisdiction is not concordant with the criteria established for same. Jurisdiction may not be waived or declined if the litigious case is connected to Spain and the other States considering the case have declined their jurisdiction, nor when it is a question of recognising and enforcing court judgments, arbitration awards and mediation agreements delivered by foreign courts and panels "unless it is an area whose jurisdiction is vested exclusively in Spanish courts and panels".

Lastly, section 68 is completely new as it regulates "international lis pendens" and it can be summarised by saying that: once a proceeding has been brought before a foreign court and subsequently before a Spanish court between the same parties, the same cause of action and the same 
petition, the Spanish court, of its own motion or at the request of a party, shall stay the action until the foreign court has established its jurisdiction without having to implement the urgent measures that might be pertinent to said stay. If it is established that the foreign court does not have jurisdiction or if, at the request of either of the parties, its jurisdiction should not be established, the Spanish court shall continue to conduct the proceeding. The stay shall be lifted if it is understood "that there are well-grounded reasons for believing that the foreign court is not going to resolve on the merits of the case within a reasonable time horizon or that the final judgment that might be delivered cannot be recognized in Spain". In any case, the decision of the Spanish court shall be delivered in accordance with the general rules and standards on lis pendens "that are regulated by the procedural laws governing each jurisdiction".

\section{CONCLUSION}

The comparison between the rules of international court jurisdiction in civil matters set forth in the LOPJ currently in force in Spain and those established in the Bill of the new LOPJ produces, in general terms, a favourable balance for the latter, for which Regulation (EC) 44/200I and Regulation (EU) I215/2012 also serve as a model, although some of the innovations introduced cannot escape criticism. Even though in some points the criteria or connecting factors for establishing international court jurisdiction are extended, in some cases, they still seem insufficient such as, for example, in regard to absence and presumption of death. There are also certain limitations in respect of the law currently in force that seem to fall short, such as, for example, the limitations on the area of extracontractual obligations. The legislative drafting should also be tidied up by bringing together all of one theme, for example, when determining the jurisdiction in regard to contracts subscribed by consumers and insurance policies, in order to avoid situations where a sub-section of one precept makes reference to other sections, and the same could be said in respect of grouping different areas under one heading since, as has been pointed out, the theme of succession does not seem to fit in appropriately under "obligations and contract law". In relation to exclusive jurisdiction, it would seem more appropriate that the law, instead of reproducing the text of article 24 of Regulation (EU) I215/20I2 which, moreover, it does incompletely, should make a simple reference to this precept while indicating Spain as the State concerned and adding that it extends to arbitration awards and mediation agreements made abroad.

Otherwise it should be pointed out that the application of the rules that are to comprise the new LOPJ, will be residual. Therefore, they will be applied when conventional rules or European Union law are not applicable or internal rules governing specific matters, such as Regulation (EU) I215/20I2, coming into force in Spain on $10^{\text {th }}$ January of the coming 2015, the Lugano Convention of $30^{\text {th }}$ October 2007, Regulation (EC) 2201/2003, Regulation (EC) 4/2009, Regulation (EC) 1346/2000, Act $54 / 2007$, passed in Spain on $28^{\text {th }}$ December 2007, and Act 22/2003, passed in Spain on $9^{\text {th }}$ July 2003, as has been the case up to the present time. ${ }^{16}$

16 Tomás Ortiz de la Torre, J. A.: "Determinación de la competencia judicial internacional de los órganos del orden civil" [Determination of international court jurisdiction in civil matters], in Cuestiones actuales de la jurisdicción en España [Current issues in relation to jurisdiction in Spain], Real Academia de Jurisprudencia y Legislación [Spanish Royal Academy of Jurisprudence and Legislation], vol. I, Madrid, 2010, pp 684-704. 